\title{
东南沿海区域食物安全可持续发展战略研究
}

\author{
曾玉荣 ${ }^{1}$, 杜琼 $^{2}$, 陈剑平 $^{3}$ \\ （1. 福建省农业科学院，福州 350003；2. 浙江省农业科学院，杭州 310021；3. 宁波大学，浙江宁波 315000）
}

\begin{abstract}
摘要：围绕 “东南沿海区域” 即上海、浙江、福建、广东、海南五个省市以及 “森林食品安全” “海洋渔业资源战略” 两个 特色专题的食物安全可持续发展研究, 着眼于国际视野, 通过实地调查研究、统计数据分析、计量模型预测等方法, 分析影 响区域内粮食及食物可持续发展的农业自然资源禀赋、食物供给与需求变迁、食物安全保障能力及面临的主要问题, 探寻在 现有资源紧缺和国际化绿色化背景下, 确保粮食与食物可持续的发展方略。提出树立大食物观战略, 实施三产融合发展战略, 实施全绿色化、生态化战略, 实施全球化战略的食物安全可持续发展的战略思路。立足东南沿海科技需求和政策目标, 提出 包含动植物种质资源与现代育种工程、优质农产品与生态农业工程、大数据精细化农场装备管理工程等十大工程技术措施。 关键词: 东南沿海; 食物安全; 可持续发展
\end{abstract}

中图分类号: S-01 文献标识码: A

\section{Food Security and Sustainable Development in Southeast Coastal Region of China}

\author{
Zeng Yurong ${ }^{1}$, Du Qiong ${ }^{2}$, Chen Jianping ${ }^{3}$ \\ (1. Fujian Academy of Agricultural Sciences, Fuzhou 350003, China; 2. Zhejiang Academy of Agricultural Sciences, Hangzhou \\ 310021, China; 3. Ningbo University, Ningbo 315000, Zhejiang, China)
}

\begin{abstract}
This paper is based on the results of two featured projects - Forest Food Security and Marine Fishery Resources Strategy, and studies food security and sustainable development in the southeast coastal region of China that includes Shanghai, Zhejiang, Fujian, Guangdong, and Hainan. It first analyzes the agricultural natural resources endowment, the changes of food supply and demand, the food security assurance ability, and the main challenges that affect the food security in this region, using field investigation, statistical analysis, econometric model prediction, and other methods, and then explores strategies for assuring food security against the backdrop of resource scarcity, internationalization, and greenization. Moreover, it proposes to develop an overall food view, promote the integration of the three industries, and implement strategies that benefit the ecology and encourage globalization. Based on the technological needs and policy objectives of the southeast coastal region, ten engineering measures are proposed, including germplasm resources and modern breeding engineering, high-quality agricultural products and ecological agriculture engineering, big-data refined management engineering for farm equipment, etc.
\end{abstract}

Keywords: southeast coastal region; food security; sustainable development

收稿日期 : 2019-09-10; 修回日期 : 2019-09-16

通讯作者: 陈剑平, 宁波大学研究员, 中国工程院院士, 主要研究方向为植物保护、宏观农业等; E-mail: jpchen2001@126.com

资助项目：中国工程院咨询项目“国际化绿色化背景下国家区域食物安全可持续发展战略研究” (2016-ZD-09)

本刊网址：www.engineering.org.cn/ch/journal/sscae 


\section{一、前言}

“东南沿海地区” (本文专指上海、浙江、福 建、广东、海南五省市), 区域气候资源和山海资 源极为相似 [1]，与国内其他地区资源环境条件刚 性约束相比形成明显优势，但面临社会消费剧变、 资源环境条件恶化、耕地质量下降及国际粮食市场 波动等系列因素共同作用，面临着类似的食物安全 问题。同时在快速城镇化和加快推进现代农业发展 过程中, 各省市均出现了人口增长与食物消费剧增 的矛盾, 保障食物数量与质量安全任务艰巨。研究 东南沿海地区食物可持续发展战略研究, 科学研判 “十三五” 时期及到 2030 年区域粮食与食物安全演 变趋势, 不仅对保障本区域食物安全有着极其重要 的作用，对促进我国区域现代农业创新发展、协调 发展、绿色发展、开放发展和共享发展具有重大的 先行和引领战略意义。

\section{二、东南沿海区域食物安全现状与态势分析}

\section{（一）食物生产现状}

1. 粮食播种面积和产量下降，但幅度放慢

主要粮食播种面积和产量降中有稳。20072017 年粮食播种面积、产量分别减少了 $18.62 \%$ 和 $14.67 \%$ 。稻谷始终保持主导地位，但所占份额逐渐 下降，2017 年约占粮食总播种面积的 $78 \%$ 、总产量 约占粮食的 $83.05 \%$, 平均单产为 $6239.57 \mathrm{~kg} / \mathrm{hm}^{2}$,
基本与 2007 年持平。薯类、豆类、玉米、小麦等其 他粮食所占份额由 $14.53 \%$ 扩大到 $21.44 \%$ 。2017 年 东南沿海区域粮食总产量约占全国的 $3.8 \%$, 但总 需求约占全国的 $11.83 \%$, 产销缺口为 $6.834 \times 10^{7} \mathrm{t}$, 自给率仅为 $26.89 \%$ 。

2. 畜牧生产以猪肉和禽类为主，呈先增后减 态势

2017 年，东南沿海区域肉类总产量约为 $8.603 \times 10^{6} \mathrm{t}$, 比 2007 年增长 $17.34 \%$, 总量约占全 国 $10 \%$ 。奶类总产量为 $6.581 \times 10^{5} \mathrm{t}$ 、禽蛋总产量 约为 $1.138 \times 10^{6} \mathrm{t}$, 分别比 2007 年下降 $11.51 \%$ 和 $1.17 \%$ （见表 1)。

3. 蔬菜生产呈增长态势, 种植面积、产量大幅 增加

2017 年，东南沿海区域蔬菜种植面积为 $2.947 \times 10^{6} \mathrm{hm}^{2}$, 产量约为 $7.965 \times 10^{7} \mathrm{t}$, 分别占全 国的 $13.77 \%$ 和 $10.77 \%$ 。从 2007 - 2017 年趋势看, 蔬菜种植面积增长 $15.2 \%$, 产量增长 $27.32 \%$ 。

4. 水产品产量占全国 $1 / 3$ 以上，水产养殖比例 逐渐提升

2017 年，东南沿海区域水产品总产量约为 $2.461 \times 10^{7} \mathrm{t}$, 约占全国的 $36 \%$, 其中海水产品约占 全国的 51\%，淡水产品约占全国的 $20 \%$ 。淡水养殖 产量提升较为快速, 海洋捕捞能力和水平有所下降。

5. 水果、森林食品生产大幅增长，产量水平快 速提升

2017 年，东南沿海 区域果园的面积约为

表 12007 -2017 年东南沿海区域主要食物的生产情况及其变动趋势

\begin{tabular}{lcccccccccccc}
\hline 时间/年 & 稻谷 & 小麦 & 玉米 & 大豆 & 其他粮食 & 蔬菜 & 水果 & 肉类 & 蛋类 & 奶类 & 水产品 \\
\hline 2007 & 2401.66 & 44.75 & 84.59 & 54.16 & 393.50 & 6255.67 & 2418.93 & 733.13 & 115.10 & 74.37 & 1794.47 \\
2008 & 2397.34 & 41.37 & 76.68 & 40.56 & 368.60 & 6387.06 & 2543.60 & 804.91 & 116.08 & 73.87 & 1825.14 \\
2009 & 2461.94 & 46.99 & 85.54 & 41.38 & 377.22 & 6547.27 & 2559.95 & 835.09 & 115.29 & 70.95 & 1890.40 \\
2010 & 2426.69 & 45.48 & 87.24 & 40.58 & 366.09 & 6757.36 & 2644.52 & 864.84 & 114.75 & 75.13 & 1972.85 \\
2011 & 2468.85 & 52.41 & 92.45 & 41.29 & 368.73 & 6962.87 & 2766.88 & 873.05 & 116.85 & 79.49 & 2070.73 \\
2012 & 2453.77 & 50.88 & 111.33 & 53.49 & 358.10 & 7127.99 & 2859.56 & 914.09 & 114.79 & 74.84 & 2108.86 \\
2013 & 2331.47 & 46.47 & 110.88 & 50.81 & 346.90 & 7226.23 & 2960.13 & 932.49 & 116.47 & 73.45 & 2185.10 \\
2014 & 2379.76 & 50.57 & 109.55 & 52.88 & 353.60 & 7404.70 & 3021.94 & 916.74 & 113.30 & 71.55 & 2283.33 \\
2015 & 2209.04 & 59.65 & 103.05 & 50.59 & 324.43 & 7595.69 & 3113.61 & 886.33 & 108.57 & 72.21 & 2378.68 \\
2016 & 2196.37 & 42.50 & 104.94 & 48.67 & 311.25 & 7738.53 & 3138.24 & 868.80 & 107.30 & 69.88 & 2413.89 \\
2017 & 2110.69 & 52.32 & 79.78 & 37.70 & 261.13 & 7964.92 & 3327.72 & 860.27 & 113.75 & 65.81 & 2461.27 \\
\hline
\end{tabular}

注: 数据跟据国家统计局公开资料整理。 
$1.979 \times 10^{6} \mathrm{hm}^{2}$, 约占全国的 $16.0 \%$; 水果产量 为 $3.328 \times 10^{7} \mathrm{t}$, 约占全国的 $13.4 \%$, 平均单产为 $16812.61 \mathrm{~kg} / \mathrm{hm}^{2}$ 。

此外, 东南沿海区域森林食品丰富, 2015 年森 林食品总产量为 $9.182 \times 10^{5} \mathrm{t}$, 约占全国总产量的 $21.68 \%$ [2]。其中, 森林蔬菜为 $8.965 \times 10^{5} \mathrm{t}$, 森林 粮食为 $4.081 \times 10^{5} \mathrm{t}$, 栽培油茶面积占全国油茶总 面积 $4.003 \times 10^{6} \mathrm{hm}^{2}$ 的 $17.22 \%$, 产量占全国总产量 的 $16.27 \%$ 。

\section{（二）食物消费态势}

\section{1. 人口规模与结构特点}

东南沿海区域总人口和城镇人口持续增长。 2007-2017 年，总人口从 19275.86 万人增长到 21647.51 万人, 增长 $12.3 \%$; 其中, 城镇人口增长 $29.47 \%$ 、农村人口减少 $11.65 \%$ 。

\section{2. 主要食物消费结构}

2015 年，东南沿海区域人均消费依次为: 口 粮 $119.65 \mathrm{~kg}$ 、蔬菜及食用菌 $95.61 \mathrm{~kg}$ 、干鲜瓜果类 $40.06 \mathrm{~kg}$ 、肉类 $32.34 \mathrm{~kg}$ 、水产品 $23.82 \mathrm{~kg}$ 、禽类 $14.58 \mathrm{~kg}$ 、奶类 $10.99 \mathrm{~kg}$ 、蛋类 $7.59 \mathrm{~kg}$ 。

农村人口与城市人口比较, 人均粮食消费高 出 $48.8 \%$, 肉类和禽类的消费大致相当, 其他食 物消费均为低下。其中奶类为 $-60.3 \%$ 、干鲜瓜 果类为 $-41.4 \%$ 、蛋类为 $-17.5 \%$ 、蔬菜及食用菌 为 $-4.2 \%$ 、水产品为 $-3.7 \%$ 。

3. 食物供给安全差异巨大

一是口粮、猪肉、禽类基本实现 $80 \%$ 以上自 给。 2016 年, 口粮自给率为 $80.7 \%$, 其中, 稻谷自 给率为 $84.21 \%$ 、猪肉自给率为 $93.5 \%$ 、禽类自给率 为 $80.3 \%$ 。二是粮食、牛肉、羊肉、奶类、蛋类供 不应求。此类食物产量远低于需求, 严重依赖外调。 2016 年，粮食自给率仅为 $32.7 \%$ ，牛肉为 $32.9 \%$ 、 羊肉为 $45.6 \%$ 、奶类为 $28.1 \%$ 、蛋类为 $57.0 \%$ 。三 是蔬菜、水果和水产品生产供过于求。2016 年, 蔬
菜自给率达 359.1\%、水果自给率达 $391.5 \%$ 、水产 品自给率达 $432.6 \%$; 蔬菜、水果和水产品除满足 本地的需求外, 大量供外省、外销市场; 此外, 受 季节性调剂较为频繁。

\section{三、东南沿海食物安全的可持续发展分析}

\section{（一）食物供给预测}

\section{1. 谷物：种植面积、产量基本稳定}

未来十年，在严格的耕地保护制度限制下，东 南沿海区域耕地面积减少幅度下降，但粮食种植受 到适宜耕地面积少、经济效益低下等条件限制。水 稻生产布局依然受到重视，薯类、玉米、小麦、 豆类等将有一定程度的增长, 粮食生产总体水平 基本保持稳定。东南沿海区域食物产量预测, 如 表 2 所示。

2. 蔬菜: 种植面积和产量持续增长

未来蔬菜的种植面积和产量将保持快速增长的 势头。

3. 肉类: 以猪肉和禽类为主, 增长潜力较大。

随着经济发展, 对畜禽养殖的环保要求越来越 高, 增加肉类产出需要提高规模化、生态化养殖水 平，走全绿色化、清洁化生产道路。

\section{4. 水果: 种植面积和生产能力持续提升}

东南沿海地处热带和南亚热带地区, 水、肥、 气、热条件优越, 地缘优势明显, 一直以来都是我 国最重要的水果产区。

5. 水产品：产量保持稳定增长

本区域主要面临东海和南海, 域内海、淡水资 源较丰富, 经济、科技水平较高, 水产养殖面积较 大 [3]。预计水产品产量将保持稳定增长, 捕捞产 量将进一步削减。

6. 禽蛋产品及奶制品：产量缓慢上升

受资源环境约束, 东南沿海五省（市）禽蛋及 奶制品产品产量增速缓慢。

表 22020 -2035 年东南沿海区域食物产量预测状况

\begin{tabular}{lccccccc}
\hline 时间/年 & 谷物产量 & 蔬菜产量 & 肉类产量 & 水果产量 & 水产品产量 & 禽蛋产量 & 奶制品产量 \\
\hline 2020 & 2332.86 & 8245 & 877 & 4384.77 & 2752 & 111.67 & 78.2 \\
2025 & 2325.06 & 9052 & 919 & 5238.07 & 3096 & 125.42 & 88.8 \\
2030 & 2316.15 & 9789 & 977 & 5887.91 & 3385 & 141.85 & 104.3 \\
2035 & 2324.77 & 10640 & 1024 & 6570.13 & 3671 & 155.94 & 120.8 \\
\hline
\end{tabular}

注: 数据根据东南沿海区域各省（市）专题报告资料整理。 


\section{（二）食物消费需求预测}

依据 2016 年国务院办公厅印发《中国食物与 营养发展纲要（2014-2020 年)》 [4], 以及中国营 养学会编著的《新版膳食指南》, 城乡居民食品消 费预测结果，如表 3 所示。

\section{（三）主要食物自给率预测}

根据东南沿海区域各省市预测, 至 2020 年、 2025 年、 2030 年、 2035 年的各食物消费需求量和 自给率预测, 如表 4 所示。

\section{（四）食物安全的主要问题}

总体看, 东南沿海区域的粮食安全问题可概括 为: 粮食效益低下与优质粮供给不足并存、饲料短 缺与畜禽生产不足并存、产品大量调出与大量进口 并存。

\section{1. 产品调入面临挑战}

东南沿海区域分别与苏、皖、赣、湘、桂诸省 接壤, 同中国香港及澳门毗邻, 又与中国台湾隔海 峡相望, 靠近东南亚, 地处经济活跃的亚太经济圈 中部。因此，具有利用海外资金、技术显著优势， 在开展对外经济技术与物流合作方面具有特殊的有 利条件。农产品调入调出面临挑战主要是：

(1) 主产区面临卖粮难问题。冬春两季的粮食
运输受铁路春运旺季的影响, 通关速度明显放慢, 只能转而选择成本更高的铁水联运或集装箱水路运 输方式。

（2）调入农产品质量安全监管难度大。调入农 产品的种类繁杂多样, 而且来源于不同地区, 这给 农产品的质量安全监管提出高标准、高要求。

（3）域外农业管理难度大。域外农业相比本地 农业来说, 管理起来困难多, 农业生产和经营管理 不到位, 继而农产品质量得不到保障 [5]。而且域 外农业, 农产品回流面对运输的环节, 还存在着运 输困难, 成本较高的问题。

\section{2. 保障食物有效供给的压力沉重}

(1) 粮食播种面积难以维持。在城市化与工业 化双向挤压下，不少城镇周边种粮耕地或被建设用 地替代, 或转作其他经济作物, 农业发展和粮食产 业空间不断被挤占。

(2) 肉类供需关系逐渐趋向紧张。近年来, 国 家 “粮改饲” 政策和 “减猪限禽、发展牛羊” 发展 思路成为多省调整优化畜牧业结构的方向 [6]。猪 肉产量大幅下降, 但牛羊等草食性动物的发展并未 实现快速增长。

（3）耕地资源潜力基本告罄。东南沿海区域总 体上是山多地少, 人均耕地面积不到全国人均土地 面积的 50\%。丘陵和山地面积大、宜耕地少, 耕地

表 3 东南沿海区域人均食品消费结构预测

\begin{tabular}{|c|c|c|c|c|}
\hline \multirow{2}{*}{ 主要食物类别 } & \multicolumn{2}{|c|}{ 农村居民 } & \multicolumn{2}{|c|}{ 城镇居民 } \\
\hline & 2020 年 & 2025 年 & 2020 年 & 2025 年 \\
\hline 稻米 & 95.50 & 91.33 & 94.88 & 90.13 \\
\hline 蔬菜 & 99.42 & 95.86 & 100.06 & 97.14 \\
\hline 食用植物油 & 10.23 & 10.30 & 10.23 & 10.30 \\
\hline 肉类 & 29.07 & 36.36 & 43.35 & 42.92 \\
\hline 水产品 & 21.52 & 22.65 & 22.65 & 25.85 \\
\hline 水果 & 50.64 & 54.47 & 50.97 & 55.20 \\
\hline
\end{tabular}

注：数据根据东南沿海区域各省（市）专题报告资料整理。

表 4 东南沿海区域食物需求自给率预测

\begin{tabular}{lccccccc}
\hline 时间 / 年 & 口粮自给率 & 蔬菜自给率 & 肉类自给率 & 禽蛋自给率 & 奶制品自给率 & 水产品自给率 & 水果自给率 \\
\hline 2020 & 84.55 & 307.7 & 59.12 & 32.55 & 12.68 & 297.2 & 205.8 \\
2025 & 86.15 & 316.8 & 57.63 & 33.03 & 10.99 & 286.4 & 221.3 \\
2030 & 87.15 & 320.1 & 56.85 & 34.39 & 11.53 & 281.0 & 225.6 \\
2035 & 88.24 & 325.9 & 55.22 & 33.94 & 11.85 & 267.3 & 232.1 \\
\hline
\end{tabular}

注: 数据根据东南沿海区域各省 (市) 专题报告资料整理。 
资源发展潜力有限。

(4) 农产品供需失衡矛盾突出。本区域经济发 达, 人均国内生产总值 (GDP) 已经达到中等发达 国家水平，消费者对农产品质量和安全的要求与日 俱增, 但 “买难” “卖难”矛盾突出, 中高端农产 品供不应求, 低端产品不时出现积压滞销。

3. 农产品储运管理体制、设备水平有待加强

随着生产成本增加，城市 “菜篮子” 规模化基 地普遍进入 “规模陷阱”, 大部分存在盈利难、离 开政府补助发展乏力等困难和问题。地方储备粮 油实行省、市、县三级管理体制, 往往产生 “搭 便车” 行为, 导致经济外部性的存在, 造成运输 过程的严重浪费。冷库冷链现代化储藏手段整体 建设滞后, 农产品在采后及运输过程中的损失率 达 20\% 30\% [7]。

\section{四、东南沿海食物安全可持续发展的战略 思路}

\section{（一）基本定位}

1. 东南沿海区域是国家食物安全保障非常脆弱 的地区

随着人口增长、经济社会发展以及城镇化进程 加速推进, 东南沿海区域粮食安全生产和食物安全 保障形势总体严峻, 在全国食物安全保障的总体战 略中具有重要的地位和影响作用。

2. 东南沿海区域是我国特色优质农产品重要生 产区域

本区域生态条件好, 具有发展现代高效生态农 业的后天优势, 蔬菜、水果、茶叶、坚果、水产等 多种农产品在全国占有十分重要的地位。

3. 东南沿海区域是对食物品质需求最高的地区 对农产品的需求已经从“吃饱” 逐渐转向为 “吃 好” 的状态, 安全、营养、健康食品的消费理念逐 步形成, 将对国家层面的食物安全可持续发展产生 重大及深远影响。

4. 东南沿海区域是市场化和对接国际市场的前 沿地区

随着改革开放 40 多年的发展, 东南沿海区域 已经成为中国市场化程度最高的地区，外向型农业 发展快, 是市场化和对接国际市场的前沿地区, 在 全国与全球农产品贸易格局中占据重要地位, 在我
国食物安全对外贸易、农业 “走出去” 等领域处于 领头羊的地位、具有标杆作用。

5. 东南沿海区域是促进东中西部区域产销合作 的重要地区

东南沿海区域在促进同中西部农产品等食物类 产品的产销合作中发挥十分重要的作用, 为中西部 地区的农业、农村发展提供了稳定的消费市场。

\section{（二）战略思路}

1. 树立大食物观战略, 统筹农业供给侧结构性 改革

一是确立 “稳定基本供给, 转变结构增加总量” 的大食物观原则 [8], 逐步形成东南沿海乃至全国 的食物安全发展新战略思路。二是加强东南沿海区 域间的贸易与协作，增强区域间食物调剂能力，通 过区域协作与国际贸易, 保障食物安全。三是研究 制定适应各地居民需要、适合当地农产品生产特点 的膳食指南, 尽量平衡生产与消费, 减少对外购食 物的依赖。四是围绕大食物安全观内涵, 调整优化 产业结构, 加快发展地方特色产业。

2. 实施三产融合发展战略, 推进农业全产业链 增值

当前, 东南沿海区域的农业发展整体呈现价值 形成与增值从生产领域向物流加工、农旅融合等相 关二三产业富集。为此, 一是增强科技创新能力、 科技含量, 增强农产品市场竞争力。二是促进相关 产业发展向基地化、规模化、标准化等方向发展, 提高产业稳定发展能力。三是推进农业三产融合发 展, 提高农产品附加值, 让农业延伸产业利润更多 留在农业农村 [9], 进而实现农民增收、农业发展 与农村振兴三者同步共振。

3. 发展 “两型” 农业, 实施全绿色化、生态化 战略

一是按照“资源节约型、环境友好型”的“两型” 农业的发展要求。重点推广物质循环利用、产业 立体复合循环、生产清洁节约等模式。二是大力 发展绿色农业, 通过优质优价机制倒逼产品品质, 提升质量安全水平, 最大可能减少对环境的不利 影响。三是强化创新意识, 树立科技支撑战略。 加强国际间农业科技合作与交流，加强与国家创 新体系的互动, 建立科技创新联盟, 助推 “两型” 农业。 
4. 实施全球化战略，打造对外开放新高地

合理利用国内、国外两个市场与两种资源，借 助开放合作加大粮食定价的国际话语权, 实现食物 安全的可持续发展。一是布局全球, 利用区域比较 优势参与国际经济分工, 实施农业 “走出去” 战略。 二是实施 “飞地” 战略, 拓展农业发展空间。通过 资本要素流动、产业集群打造、品牌管理辐射, 突 破土地资源约束的瓶颈，实现飞地型食物生产基地 资源扩容。三是建立面向全国及世界性的农业资源 开放性创新平台、自主创新孵化平台和服务平台, 获取全球研发机构的外溢效益、国际科技资源和产 业关键技术 [10]。

\section{（三）战略目标}

1. 食物产量及自给率目标

至 2020 年, 粮食产量 5 年内年均增长 $1.51 \%$; 至 2035 年, 粮食产量年均增长 $0.1 \%$, 自给率力争 保持在 $29 \%$ 水平。

至 2035 年, 蔬菜、水果、水产品自给有余; 肉类自给率达 $68 \%$ 以上, 禽蛋自给率达 $37 \%$ 以上, 奶及其制品自给率达 $12 \%$ 以上。

\section{2. 农产品质量安全水平目标}

至 2020 年，农产品质量安全例行监测总体合 格率达 $96 \%$ 以上, 粮、油、肉、蛋、乳五大类大 宗日常消费品评价性抽检合格率稳定在 $95 \%$ 以上。

\section{五、东南沿海食物安全可持续发展的战略路 径与科技工程}

\section{（一）战略路径}

1. 保护、提升粮食生产潜力, 实施 “藏粮于地、 于技” 战略

（1）重点保持耕地的肥力与生产力。以培肥地 力、改良土壤、平衡养分、质量修复为主要内容, 优先推进秸秆就地还田快速降解生物技术研究, 探 索设立工程建设表层有机土质资源储存制度, 为特 殊情况下快速提升粮食生产能力做好准备工作。加 快中低产田改造步伐, 示范推广 “千斤粮万元钱” 等绿色增产模式 [11], 优化品种结构。

（2）提升基础设施建设水平并完善管护机制。 加快实施大中型灌区续建配套和更新改造, 筹划大 型水利工程以及粮食配套设施建设, 提高农田有效
灌溉的比例。大力抓好小型农田水利设施建设, 重 点建设田间灌排渠系和抗旱水源工程 [12]。

2. 综合提升粮食生产安全, 稳 “水” 增 “早” 适调结构

（1）牢固树立 “大粮食安全观”。拓展早粮补 贴类别, 积极开发利用低丘缓坡地带与越冬田, 大 力发展特色旱粮产业, 提高旱杂粮生产效益与粮 食生产整体效益 [10]。建议将鲜食玉米与红薯纳 入本区域主粮范畴, 在政策上享受与水稻、小麦 同等待遇。

（2）加快确立优质水稻产业体系。以保障 “口 粮绝对安全” 为前提, 满足东南沿海区域中高端大 米消费需求持续增长的趋势, 允许甚至鼓励该区 域将优质水稻的栽培面积作为粮食安全的首要衡 量指标。

3. 瞄准中高端、精品化市场定位, 提升农产品 市场竞争能力

适应东南沿海区域社会经济快速发展和国际化 趋势, 粮食安全保障应加速从 “增产导向” 转为 “提 质导向” [13]。

（1）打造中高端农产品生产体系。大力建设优 势高端特色产业集聚区, 着重优化产品结构、产业 结构、区域结构 [14]。

（2）构筑中高端农产品生产环境与农作制度。 综合采取农机、农艺、工程和生物措施, 构建具有 东南沿海区域特色的保护性耕作技术体系。推行“标 准化 +”农业, 并优化产业化利益联结机制, 使之 成为农民增收的可持续源泉。

（3）构筑中高端农产品品控管理体系。重点推 广 “区域公共品牌母品牌 + 企业自有品牌子品牌” 品牌化发展模式; 加强农产品品控认证, 推进投入 品 GMP 认证、种植业产品 GAP 认证、畜禽水产养 殖及加工业公顷 CCP 认证和 “二品一标” 质量认证; 在规模以上生产主体中推行档案登记制度, 探索建 立覆盖生产和流通环节的质量追溯、风险预警和应 急反应处置体系。

4. 面向丰富的山海资源, 挖掘 “蓝色粮仓”及 森林食品潜能

根据各省公开统计数据计算, 东南沿海区域 山地、丘陵占总面积的 $70 \%$ 以上, 海洋面积约为 $2.82 \times 10^{6} \mathrm{~km}^{2}$, 占全国海洋面积的比例约为 $94 \%$, 山海资源极为丰富。 
（1）重点发展海洋渔业产业经济 [15]。开展渔 业资源承载力调查研究, 加强沿海渔业资源养护, 恢复区域性海洋渔业生态; 大力发展生态海洋水产 养殖业, 使 “蓝色粮仓” 由浅蓝迈向深蓝, 拓展渔 业发展空间, 打造成为区域性最具市场竞争力的农 业产业之一; 创新沿岸渔业产权管理模式, 使沿岸 渔场利用权属地化, 并推动近海滩涂水产养殖减量 增效, 提升生产能力与品质 $[16,17]$ 。

（2）增强森林食品资源培育水平 [18]。充分利 用低丘缓坡资源与林业资源, 大力发展以森林粮食 和木本油料、肉类为区域食物安全增长潜力点。以 森林食品种植为核心, 示范和推广森林食品生态复 合经营模式, 恢复和提高林地生产力, 促进森林食 品产业链延伸。

5. 充分调动国内外两个市场、两种资源, 优势 互补, 稳定农产品市场供给

（1）加强与长江经济带中上游区域协作, 稳定 粮畜供应。把长江经济带打造为粮食与畜禽的稳定 供应基地。加强与中国台湾精致农业技术合作，加 快构建中高端农产品生产体系、产业体系。

（2）加强与 “一带一路” 沿线国家合作。鼓励 农业企业赴沿线国家和地区从事农业合作开发，重 点支持粮食及油料作物种植、农畜产品养殖等项目。

（3）建设水产品、果蔬出口生产基地, 发展外 向农业。建立一批优势出口水产品、果蔬产业外销 基地, 扩大出口, 消化产能, 推进 “出口替代” 战略。

\section{（二）重大科技工程}

挖掘区域资源优势, 树立区域品牌, 引领东南 沿海各区域率先走向中高端农产品, 引领农业高质 量发展, 如加强高效优质多抗新品种选育和推广、 发展多种形式适度规模经营、打造品牌农业等。

1. 动植物种质资源与现代育种工程

一是发掘生物种质资源和探索在植物作物育种 上新的利用技术。二是运用分子设计育种培育突破 性品种并催生智能植物品种的诞生。加强食物安全 关键工程技术研发：包括现代种业关键技术，实施 动植物遗传改良计划和种业提升行动, 推进新一轮 品种更新换代; 养殖业安全绿色生产关键技术, 如 新型饲料资源开发、疫病综合防控、品质检验技术、 健康养殖技术等；农产品产后增值关键技术、智能 化精深加工等技术研究; 农产品数量安全、质量安
全控制关键技术; 农业生态环境保护关键技术研 发、集成推广; 农田环境智能监测技术、数字农业 智能管理技术、智慧农业生产技术及模式、智慧设 施农业技术，以及数字化精准化短期及中长期预警 分析系统的研发、集成示范和推广应用等。

2. 优质农产品与生态农业工程

围绕农田生态修复与安全生产、面源污染控制、 乡村环境综合治理和生物多样性保护与利用, 开展 农业生产系统建构与平衡机理研究, 加快建设农业 绿色发展科技支撑体系, 如污染治理与循环农业工 程、生态环境质量安全科技工程、农产品质量安全 过程控制技术体系。

\section{3. 大数据精细化农场装备管理工程}

构建集约、高效、安全、持续的智慧农业科技 支撑体系，满足现代农业产业发展对机械装备的紧 迫需求, 推动高质量现代农业和绿色美丽经济。包 括推动农产品生产、流通领域的 “数字农业”信息 工程技术，适用于中小型、高速、复式作业农业装 备制造技术，平原、丘陵、山地、林地等区域的智 能化关键装备。

\section{4. 营养健康食品产业化工程}

满足国民膳食消费结构和营养调整要求, 加 强营养健康食品研发理论和创制关键技术及装备研 究, 实现营养健康食品的产业化开发和跨越式发展。

(1) 对于特色健康营养食品开发, 研究挖掘农 产品中的健康功能组分, 研究提取分离和稳态化技 术, 利用现代加工方法开发健康功能产品。加强新 资源食品、特色农产品和药食两用农产品资源评价 与开发利用。

（2）对于特色食品现代化生产技术，研发节能 高效现代食品加工关键装备和成套生产线, 提升食 品感官品质和理化特性, 实现机械化、标准化和产 业化。

（3）对于保鲜与物流技术, 着重破解食品在物 流过程中的品质劣变与损耗等难题。

（4）对于食品加工机械装备, 积极开展新型杀 菌、节能干燥和高速包装等核心关键技术装备集成 与开发。

\section{5. 全产业链融合再创新工程}

加快 “农业+”综合集成, 开展农业产业跨界 技术综合集成研究、融合嫁接和再创新。

(1) 开发、拓展和提升农业的多种功能, 培育 
中高端农产品品牌的知名度和美誉度。

（2）大力扶持渔业实体经济, 从单一的远洋捕 捞向全产业链、多元化综合经营延伸。

6. 农田生态系统生物多样性工程

坚持节约优先、保护优先、自然恢复为主的方 针，形成节约资源和保护环境的空间格局。

(1) 耕地生物多样性对养分高效利用和有害生 物发生的影响机制。包括耕地质量、生物多样性、 灌溉模式 (滴灌、漫灌)、机械化等与耕地有害生 物发生和灾变规律的影响研究 [19]。

（2）实施重要生态系统保护和修复重大工 程 $[20,21]$ 。一是加强农田生物生境、水体恢复与保 养、生态植被提升、耕地质量保护, 提升生态系统 质量和稳定性。二是强化土壤污染管控和修复, 加 强农业面源污染防治, 加强固体废弃物和垃圾处置。 三是完善天然林保护制度, 强化湿地保护和恢复。 四是严格保护耕地, 扩大轮作休耕试点, 建立生态 补偿机制。

\section{7. 基于高附加值的农产品精深加工工程}

开展高附加值农产品原料理化特性、营养特性、 贮藏及加工特性、功能特性、加工技术标准、副产 物综合利用研究。

（1）基础研究: 如在咜运和加工过程中营养品 质变化研究、营养组分相互作用机理研究、农产品 生物制造前沿技术基础研究等。

（2）技术开发: 开展新型非热加工、绿色节能 干燥、高效分离提取、长效减菌包装和清洁生产技 术升级与集成应用; 开展酶工程、细胞工程、发酵 工程及蛋白质工程等生物制造工程化技术研究与装 备研制。

（3）实施营养和保健功能食品的科技研发。开 发功能性及特殊人群膳食相关产品、保健功能食品、 营养素食特色食品等。

\section{8. 基于绿色化、环保型的畜离工厂化工程}

在资源与环境有限承载力下 [22], 发展环保型 绿色化、工厂化畜禽生产, 加快畜牧业转型升级, 发展高效益、高质量的现代畜牧业。加快制定和实 施畜牧、饲料质量安全标准; 加强检验检测、安全 评价和监督执法体系建设, 强化监管能力; 全面实 施畜禽标识制度和牲畜信息档案制度, 完善畜产品 质量安全监管和追溯机制。

\section{9. 海洋生物资源可持续开发利用工程}

明确 “聚焦深海, 拓展远海, 深耕近海” 三大 发展方向, 围绕海洋特有的群体资源、遗传资源、 产物资源三类生物资源, 一体化布局海洋生物资源 开发利用重点任务创新链, 保障我国食品安全 [17]。 一是深海生物科学与资源评价。由国家财政部、 农业农村部等相关部门统一协调、统一布局和加大 投入，制定国际海洋渔业资源调查计划。提升深海 生物资源探查获取能力, 开展深海生命科学前沿与 应用研究 [23]。二是开发远洋生物资源, 提高南极 磷虾等战略性新资源综合利用水平, 远洋生物新资 源的探查和评价、捕捞关键技术与装备研发等。三 是开展近海海洋生物多样性研究和生物资源评估, 建立近海生态保护技术体系。四是创新海洋药物与 高端生物制品研究与开发, 建立新型海洋产品加工 技术体系、全产业链无缝化安全控制技术。五是开 展渔场修复与海洋 “蓝色粮仓”建设, 形成产业链 完整的 “蓝色粮仓”产业集群 [24]。

\section{0. 森林食品科技创新工程}

在稳健发展主要森林食品的同时, 适度提升森 林食品对粮食安全的贡献。包括林下种养模式, 逐 步实现规模化、标准化、安全化生产; 森林食品产 品认证, 推进森林资源高效培育与质量精准提升科 技工程; 建立健全相关种质资源收集保存和良种生 产研发与供应体系, 提高单产水平。

\section{参考文献}

[1] 伍世代, 王强. 中国东南沿海区域经济差异及经济增长因素分 析 [J]. 地理学报, 2008 (2): 123-134.

Wu S D, Wang Q. Regional economic disparities and coordination of economic development in coastal areas of Southeastern China [J]. Journal of Geography, 2008 (2): 123-134.

[2] 赵从娟, 刘庆博, 宋莎. 我国森林食品相关研究进展 [J]. 中国林 业经济, 2015 (3): 76-78.

Zhao C J, Liu Q B, Song S. Research progress of forest food in China [J]. Forestry Economy of China, 2015 (3): 76-78.

[3] 徐汉祥. 跨世纪东海渔业资源利用和管理若干问题的探讨 [J]. 浙江海洋学院学报(自然科学版), 2000 (3): 197-203.

$\mathrm{Xu}$ H X. Discussions on the issues of trans-century marine fishery resource exploitation \& its management in the East China Sea [J]. Journal of Zhejiang Ocean University (Natural Science Edition), 2000 (3): 197-203.

[4] 赵丽云, 刘素, 于冬梅, 等. 我国居民膳食营养状况与《中国食 物与营养发展纲要(2014-2020年)》相关目标的比较分析 [J]. 中国食物与营养, 2015, 21(8): 5-7.

Zhao L Y, Liu S, Yu D M, et al. Comparative analysis of dietary 
nutrition status of Chinese residents and related targets of Chinese food and nutrition development program ( 2014-2020) [J]. China Food and Nutrition, 2015, 21(8): 5-7.

[5] 潘镜平. 浦东新区域外农业经济发展研究 [J]. 上海农村经济, 2015 (1): 19-22.

Pan J P. Study on the development of extra-regional agricultural economy in Pudong New Area, Shanghai [J]. Shanghai Rural Economy, 2015 (1): 19-22.

[6] 郑瑞强, 刘小春, 杨丽萍. “粮改饲”政策效应分析与关键问题研 究观点 [J]. 饲料工业, 2016, 37(3): 62-64.

Zheng R Q, Liu X C, Yang L P. “Grain for forage” policy effect analysis and key issues research review [J]. Feed Industry, 2016, 37(3): 62-64.

[7] 李志聪, 施云清. 农产品物流配送中心选址优化研究 [J]. 现代 营销(下旬刊), 2018 (7): 101-102.

Li Z C, Shi Y Q. Research on location optimization of agricultural products logistics distribution center [J]. Modern Marketing (Late issue), 2018 (7): 101-102.

[8] 程广燕, 王小虎, 郭燕枝, 等. 大食物理念下国家粮食安全保障 需求与途径对策 [J]. 中国农业科技导报, 2017, 19(9): 1-7.

Cheng G Y, Wang X H, Guo Y Z, et al. National grain security assurance requirement, ways and countermeasures under concept of "Big Food" [J]. China Agricultural Science and Technology Report, 2017, 19(9): 1-7.

[9] 谭明交. 农村一二三产业融合发展: 理论与实证研究 [D]. 武汉: 华中农业大学(博士学位论文), 2016.

Tan M J. Theoretical and empirical research on convergence development of primary, secondary and tertiary-industry in rural areas [D]. Wuhan: Huazhong Agricultural University (Doctoral dissertation), 2016.

[10] 梁文化. 中国OFDI逆向技术溢出对自主创新的影响研究 [D]. 北京: 首都经济贸易大学(博士学位论文), 2017.

Liang W H. Research on the impact of China's OFDI reverses technology spillover to independent innovation [D]. Beijing: Capital University of Economics and Trade (Doctoral dissertation), 2017.

[11] 徐文慧. 浙江省稻田 “千斤粮万元钱”农作模式技术探讨 [D]. 杭州: 浙江大学(硕士学位论文), 2016.

Xu W H. Research on technology of the paddy field farming system producing more than half-a-ton of grain and ten-thousand yuan of income per mu yearly in Zhejiang province [D]. Hangzhou: Zhejiang University (Master's thesis), 2016.

[12] 解国荣. 加强小型农田水利工程运行维护管理的对策措施 [J]. 珠江水运, 2018 (6): 50-51.

Xie G R. Measures to strengthen the operation, maintenance and management of small-scale farmland water conservancy projects [J]. Pearl River Water Transport, 2018 (6): 50-51.

[13] 李圣军. 新时代我国粮食安全保障思路 [J]. 农业发展与金融, 2019 (6): 25-27.

Li S J. Thoughts on food security in China in the new era [J]. The Agricultural Development and Finance, 2019 (6): 25-27.

[14] 史云, 杨相合, 谢海英, 等. 农业供给侧结构性改革及实现形
式一一田园综合体 [J]. 江苏农业科学, 2017, 45(24): 320-326. Shi Y, Yang X H, Xie H Y, et al. Agricultural supply-side structural reform and its realization form-pastoral complex [J]. Jiangsu Agricultural Sciences, 2017, 45(24): 320-326.

[15] 胡求光, 王秀娟, 曹玲玲. 中国蓝色牧场发展潜力的省际时空差 异分析 [J]. 中国农村经济, 2015 (5): 70-81.

Hu Q G, Wang X J, Cao L L. Interprovincial spatial-temporal difference analysis of development potential of blue ranch in China [J]. Chinese Rural Economy, 2015 (5): 70-81.

[16] 王波, 倪国江, 韩立民. 产业结构演进对海洋渔业经济波动的影 响 [J]. 资源科学, 2019, 41(2): 289-300.

Wang B, Ni G J, Han L M. Impact of the evolution of industry structure on the economic fluctuation of marine fishery [J]. Resource Science, 2019, 41(2): 289-300.

[17] 李琪. 中国海洋产业经济发展中的问题与对策 [J]. 经济师, 2019 (4): $10-11$.

Li Q. Problems and countermeasures in the economic development of China's marine industry [J]. Economist, 2019 (4): 10-11.

[18] 胡侠. 发展现代林业经济 力乡村振兴战略 [J]. 浙江林业, 2018 (10): 4-5.

$\mathrm{Hu} \mathrm{X}$. The strategy of developing modern forestry economy to boost rural rejuvenation [J]. Zhejiang Forestry, 2018 (10): 4-5.

[19] 李亮科. 生产要素利用对粮食增产和环境影响研究 [D]. 北京: 中国农业大学(博士学位论文), 2015.

Li L K. The research on how utilization factors of agricultural production impact grain production and environment [D]. Beijing: China Agricultural University (Doctoral dissertation), 2015.

[20] 统筹山水林田湖草系统治理 生态文明建设迈向新高度 [J]. 国 土绿化, 2018 (5): 1.

Overall planning of landscape, forestry, field, lake and grass system for ecological civilization construction has reached a new height [J]. Land Greening, 2018 (5): 1.

[21］张惠远, 郝海广, 翟瑞雪, 等. “十三五”时期国家生态安全的若 干问题及对策 [J]. 环境保护, 2017, 45(1): 25-30.

Zhang H Y, Hao H G, Zhai R X, et al. Issues and suggestions on constructing ecological security during the "13th Five-Year" period [J]. Environmental Protection, 2017, 45(1): 25-30.

[22] 高湘昀, 安海忠, 刘红红. 我国资源环境承载力的研究评述 [J]. 资源与产业, 2012, 14(6): 116-120.

Gao X Y, An H Z, Liu H H. Views on China's resources and environmental loading capacity [J]. Resources and Industry, 2012, 14(6): 116-120.

[23] 李政道. 粤港澳大湾区海陆经济一体化发展研究 [D]. 沈阳: 辽 宁大学(博士学位论文), 2019.

Li Z D. Development research on marine-inland economic integration in Guandong-Hong Kong-Macau Greater Bay Area [D]. Shenyang: Liaoning University (Doctoral dissertation), 2019.

[24] 杨红生, 邢丽丽, 张立斌. 现代渔业创新发展函待链条设计与原 创驱动 [J]. 中国科学院院刊, 2016, 31(12): 1339-1346.

Yang H S, Xing L L, Zhang L B. Promoting systematic design and innovation-driven development for modern fishery [J]. Journal of the Chinese Academy of Sciences, 2016, 31(12): 1339-1346. 